\title{
Structural Evidence for Glucagon Producing Cells in the Intestinal Mucosa of the Rat*
}

\author{
Lelio Orot, Ruymond Pictet, Wolf G. Forssmane, Albert E. Renold, and Charles Roullueb
}

Department of Histology and Embryology, and Department of Clinical Biochemistry, University of Geneva, Switzerland

Received August 4, 1967

\begin{abstract}
Summary. The gastro-intestinal mucosa of the rat has been systematically studied with the electron-microscope at the following levels : gastric fundus, pylorus, duodenum, jejunum and ileum. Two types of non-digestive epithelial cells have been observed, both exhibiting electron-dense granulations, both candidates for endocrine activity. The first type of cells contains round granules bearing remarkable similarity to the granules of pancreatic endocrine A cells. The second cell type is characterised by strikingly polymorphic granulations and would appear to correspond to the so-called enterochromaffine cells of light-microscopy. On the basis of this morphological criterion, and of the biochemical evidence suggesting the existence of a substance in the intestine which greatly resembles glucagon, biologically and immunologically, it is proposed that this substance is secreted by the first type of cells which resemble the pancreatic A cells.
\end{abstract}

Mise en évidence par la microscopie électronique de cellules à glucagon dans la muqueuse digestive du rat

Résumé. L'étude au microscope électronique de l'intestin de rat à différents niveaux: estomac, duodénum, jéjunum et iléon, permet d'observer 2 types de cellules à granulations denses. Le premier type, dont les granulations sont rondes, est semblable aux cellules A du pancréas. Le deuxième type de cellules, dont les granulations sont polymorphes, est associé aux cellules dites entérochromaffines. Sur la base de ce critère morphologique, et des données biochimiques affirmant l'existence dans l'inte- stin d'une substance biologiquement et immunologiquement proche du glucagon, il est proposé de situer la synthèse et sécrétion du glucagon intestinal au niveau de ces cellules endocrines intestinales de type $A$.

Elektronenmikroskopische Darstellung von Glucagon-produzierenden Zellen im Gastrointestinaltrakt

Zusammenfassung. Bei einer systematischen Untersuchung der Magen-Darm-Schleimhaut mit Hilfe des Elektronenmikroskopes wurden zwei Arten von besonderen Zellen in deren Epithelien festgestellt, die mögliche Träger endokriner Tätigkeit sind. Beide sind durch elektronenoptisch dunkle Granula gekennzeichnet. Der erste Typ enthält runde Einschlüsse, die den Sekret-Granula der endokrinen A-Zellen des Pankreas sehr ähnlich sind. Der zweite Zelltyp weist auffallend polymorphe Sekretgranula auf, die derjenigen der sogenannten enterochromaffinen Zellen im Lichtmikroskop entsprechen dürften. Diese morphologische Eigenschaft sowie die biochemischen Beobachtungen, welche auf das Vorhandensein einer dem Glucagon biologisch und immunologisch ähnlichen Substanz im Darm deuten, lassen die Annahme zu, daß die den pankreatischen A-Zellen ähnlichen Zellen für die Sekretion des Darm-Glucagons verantwortlich sind.

Key-words: Glucagon, Enteroglucagon, Intestinal mucosa, Intestinal hormones, Enterochromaffine cells, Electron microseopy of gastrointestinal mucosa.
It is recognised that there are, in the stomach and the intestine, cells which do not appear to be active in digestion, and which are most frequently found at the base of the gastric glands and of the glands of LIEBERKUHN. These cells are usually designated as cells of Nicolas or KuLTsCHISKY, and also as enterochromaffine or argentaffine cells because of their characteristic affinity for chromium or silver. As a rule, it has been thought that these tinctorial properties define a single cell type. In 1952, Erspamer and AsEro [6] reported that the secretory product of these cells is 5-hydroxy-tryptamine or serotonin. In 1961, LusE and LACY [22] confirmed the association of argentaffine cells and over-production of serotonin in a carcinoid tumour and, with the help of the electron-microscope, described the presence of cells with dense granules of irregular, mostly oblong shape.

To our knowledge, the systematic characterization

* Supported in part by grants No. 4237 and 3618 of the Fonds National Suisse de la Recherche Scientifique, Berne, Switzerland. of the morphology of intestinal cells has not as yet been accomplished. The rather scant studies which have been devoted to the electron-microscopy of the digestive tract have been limited, either to specific portions of the system $[8,3,19]$, or to a given digestive function $[11,33,34,36]$. In each instance, whenever cells with dense granulations were observed, and when the likelihood of the secretion of proteolytic enzymes could be excluded, these cells were classified by exclusion as enterochromaffine or argentaffine cells [11, 13, 191. Although this preliminary conclusion was a reasonable one, it is necessary to recall that there is as yet no evidence definitely establishing the identity of the cells with dense granules seen with the electron microscope with the argentaffine or enterochromaffine cells seen with light microscopy. Furthermore, recent physiologic observations suggest that the intestine may well contain several types of cells with distinct endocrine function $[16,25,32,37,40,41]$.

In 1948, Sutherland and $\mathrm{De}_{\mathrm{e}}$ Duve [37] demonstrated the existence of a "glucagon-like" hypergly- 
caemic factor in the intestine. More recent studies have established that the intestinal tract does indeed contain substances which are both immunologically and biologically related to glucagon. It becomes necessary, therefore, to assume that the intestine contains at least two types of endocrine cells, one concerned with the secretion of serotonin, the other with that of glucagon. The purpose of this paper is that of reporting that the electron-microscope allows the distinction of at least two types of cells containing dense granulations, of which one bears a remarkable resemblance to the $A$ cells of the endocrine pancreas, that is to the cells considered to be the likely source of pancreatic glucagon $[29 \mathrm{a}]$.

\section{Materials and Methods}

The animals used were Wistar rats raised in our own colony, weighing between 200 and $300 \mathrm{~g}$ and fed ad libitum. The tissues were fixed by perfusion [7a] of the whole animal with an isotonic $2.3 \%$ glutaraldehyde solution in cacodylate buffer adjusted to $\mathrm{pH}$ 7.45. Tissue samples were obtained at the level of the gastric fundus, of the pylorus, the duodenum, the jejunum and the ileum. Other tissues examined included adrenal, pituitary and pancreas. They were postfixed in a $1 \%$ osmium solution in collidine buffer. The fixation was carried out at $4^{\circ} \mathrm{C}$ throughout. After dehydration in solutions with increasing concentrations of ethanol, the tissues were embedded in Epon according to the technique described by LuFT [21]. Semi-thin sections for scanning purposes were observed with a phase-contrast microscope [26] or, in certain instances, after staining with methylene blue. Thin sections were stained according to KARNOVsKY [15] and studied with the electron-microscope Zeiss EM9.

\section{Results}

In the intestinal mucosa of the rat, at least two distinct cell types with dense granules are seen, and this at all levels studied : stomach, duodenum, jejunum and ileum. The first type (Figs. 1, 4, 5, 7, 8) exhibits round intra-cytoplasmic granulations surrounded by a rather tightly fitting membrane. The diameter of these granules averages $250 \mathrm{~m} \mu$. The second type (Figs. 2, $6,10)$ exhibits polymorphic granules, which appear, in cross-section, oval, kidney- or pear-shaped, and also, occasionally, round. Although the granules of these two cell types are clearly different, these cells are otherwise remarkably similar. Thus, they are both localized most often close to the base of the glandular epithelial cells, or, less frequently, of the epithelial cells of the villi. In the intestine, their shape is pyramidal, with the base facing the sub-mucosa. Their cytoplasma is less dense than that of the neighbouring epithelial cells and contains many filaments, which may be single or grouped in bundles (Figs. 4, 5 et 6 ). The endoplasmic reticulum is predominantly peri-nuclear, leading to the formation of concentric circles on cross-section (Fig. 10). As a rule, the Golgi complex is localized at the apical pole of the nucleus and there is suggestive evidence for its participation in the genesis of the granules (Fig. 1). The largest number of granules is found between the nucleus and the base of the cell. A relationship between the cells and the intestinal lumen has not been observed. In the stomach, these cells are round, contain less filaments and do not exhibit the internal polarization just described.

The granules of the first cell type resemble the granules of the pancreatic A-cells (Figs. 3, 14). However, their packing is less dense than in the pancreatic cells, and the ratio of nucleus to cytoplasm is larger. There is also, as in stomach, no polarization of the Golgi complex in the pancreatic A cells and cytoplasmic filaments are much less abundant. These differences may well be secondary to the different localization of the pancreatic and intestinal cells, expressing differences in the architecture of the two tissues.

At the level of the pylorus only, two further types of cells have been seen (Figs. 9, 11, 12, 13) both seemingly related to the lumen of the glands. These cells are rounded and contain numerous granules, though more variable in size than is true for the two types of cells already described. The contents of the granular vesicles are very much less electron-dense in the exclusively pyloric cells (Figs. 11, 12, 13). These two additional cell types differ from each other in the dimensions of granules and vesicles, the second type being characterized by much smaller vesicles, containing small granules of low density (Fig. 11).

All of these cells are clearly distinct from mucuscontaining glandular cells (Fig. 12), which exhibit a characteristic Golgi complex next to the apical pole of the nucleus and closely associated with the secretory product contained in very much larger vesicles than is true for the granulations of the cells described in this report. Mucoid secretions are furthermore poorly contrasted after staining with osmium or lead. We have also seen cells clearly similar to pancreatic D-cells $[29 \mathrm{~b}, 7 \mathrm{~b}]$ as described by SoLcra and collaborators [35].

We are well aware of the fact that the distinction made here between different types of cells is based to a large extent on the morphological evaluation of the granules. In order to analyze further whether granular morphology is a valid criterion for the characterization of hormonal synthesis or secretion, we have also studied in the same animals other cells, the function of which is well known. Thus, in the endocrine pancreas, granular morphology is a major element in recognizing $A$ (Figs. 3, 14) from B cells (Fig. 15): the fit of the membrane is very much looser for B-cell granules, and the space between the granule and the membrane appears empty $[1,17,28]$. In certain instances, the classification is greatly facilitated by the presence, in $B$ vesicles and only in $B$ vesicles, of crystalloid structures replacing the granule. The diameter of both $\mathrm{A}$ and $\mathrm{B}$ granules is approximately $250-300 \mathrm{~m} \mu$. 
Similarly, in the adrenal medulla (Fig. 16), the cells secreting epinephrine or nor-epinephrine clearly differ from each other [5]. Not only is the cytoplasm of the cells secreting nor-epinephrine denser, but their granules exhibit an almost metallic sheen and often appear to be fused to a portion of the vesicular membrane, leaving a wide, empty space in the remainder of the vesicle. By contrast, epinephrine-secreting cells exhibit granulations which are less dense, well-rounded, and well centred in the vesicle, which fits rather closely. The mean diameter of these granules is approximately $150-200 \mathrm{~m} \mu$.

As a third example of the importance of granular morphology in the identification of cells, we shall cite the classification of anterior pituitary cells according to the hormone produced: Fig. 17 shows three STHproducing cells separated by a TSH-producing cell : the granules of the STH-producing cells are in much closer contact with their granular membranes (Fig. 17, Fig. 18) than is true for the TSH-producing cell granules which, furthermore, are very much smaller $[30,38,42]$.

\section{Discussion}

Analysis of the endocrine pancreas with the light microscope allows for differentiation of $B$ cells from non- $B$ cells. The identification is made possible by the specific staining characteristies of $B$ cells $[9,10]$ as well as the alterations seen either in spontaneous diabetes $[20,23,30]$ or after the administration of agents such as alloxan [4] or streptozotocin [14], which lead to diabetes, and to the disappearance of both $\mathrm{B}$ cells and insulin from the pancreas.

The further differentiation of non-B cells with light microscopy is less straight forward, although some authors distinguish A-1 cells from A-2 cells [12] the latter being non-argyrophile and secreting glucagon. Other authors consider the argyrophile cells as being closely related to D-cells $[2,3]$ and possibly concerned with the as yet not definitely established pancreatic secretion of gastrin. This association has been suggested by the abundance of $\mathrm{D}$-cells in some pancreatic tumours which appear to be functionally characterized by hypersecretion of gastrin [3]. As yet no classification is universally accepted and it is unlikely that such acceptance will be forthcoming in the near future, since authors such as MaNocchio [24] even suggest that the glucagon-producing cells may well be argyrophile, whereas LEE [18] describes the likely identity of argyrophile cells seen with light microscopy with the A cells of electron miscroscopy. Nevertheless, we presently subscribe to the view that the A-1 cells resemble D-cells, and that the glucagon-secreting cells are indeed non-argyrophile and therefore of the A-2 type.

With the electron microscope, the non-B endocrine cells are at least of two kinds: A-cells (Fig. 3, Fig. 14) which are the probable sites of glucagon synthesis and secretion, and D-cells $[1,27,28]$, which are much less numerous. The probable endocrine cells of the gastrointestinal tract have many points in common with the non-B cells of the endocrine pancreas. With the light microscope, both argyrophile and argentaffine cells are seen. Both cell types have usually been grouped together and classified as enterochromaffine cells, presumably secreting serotonin. With the electron microscope, however, we have shown in the present study that these cells may well be subdivided into at least two types, one of which remarkably resembles the $A$ cells of the endocrine pancreas. These morphological criteria, therefore, would tend to support the concept of at least two types of endocrine cells in the intestinal tract, one primarily secreting glucagon. It is suggested that serotonin is synthetized and secreted in the cells characterized by polymorphic granulations, a suggestion arrived at by exclusion, the glucagon secretion being more likely localized in the cells with granulations closely resembling those of the $\mathrm{A}$ cells of the endocrine pancreas.

As already stated, this classification rests primarily on the morphology of the secretory granules themselves. Although this might seem to provide but a rather fragile basis for classification, we should like to contend that this is not the case. As very briefly illustrated by the examples shown in Figs. 14, 15, 16, 17, 18 , it is clear that endocrine cells secreting distinct hormonal products exhibit striking differences in the shape and electron density of the secretory granules as well as in their relationship to their granular membranes and the general architecture of each cell. The clear differentiation of the secretory granules in adrenal medulla cells secreting either epinephrine or norepinephrine is particularly impressive, since these hormones differ only by one methyl group.

The coincidence of the morphological resemblance between $A$ granules in the endocrine pancreas and in the corresponding cells of the intestinal tract is, of course, greatly supported by the demonstrated presence in the intestinal mucosa of one or several substances which resemble, both immunologically and biologically, the pancreatic hormone glucagon. Although quantitative studies of the relative frequency and distribution of the two types of probable endocrine cells of the gastro-intestinal tract have not yet been carried out, present observations suggest that the cells of Atype, presumably producing glucagon, are considerably less frequent than the cells with polymorphic granulations, presumably producing serotonin. It is also as yet impossible to estimate what the total number of intestinal A cells might be. Accordingly, the relative abundance of extractable intestinal and pancreatic glucagon cannot yet be compared with the relative numbers of instestinal and pancreatic A cells. It is of considerable interest, however, that both morphological and physiological criteria combine to suggest a remarkable strategic role for the glucagon-producing A cells: they are found in close approximation with insulinproducing cells within the islets of Langerhans, and in 

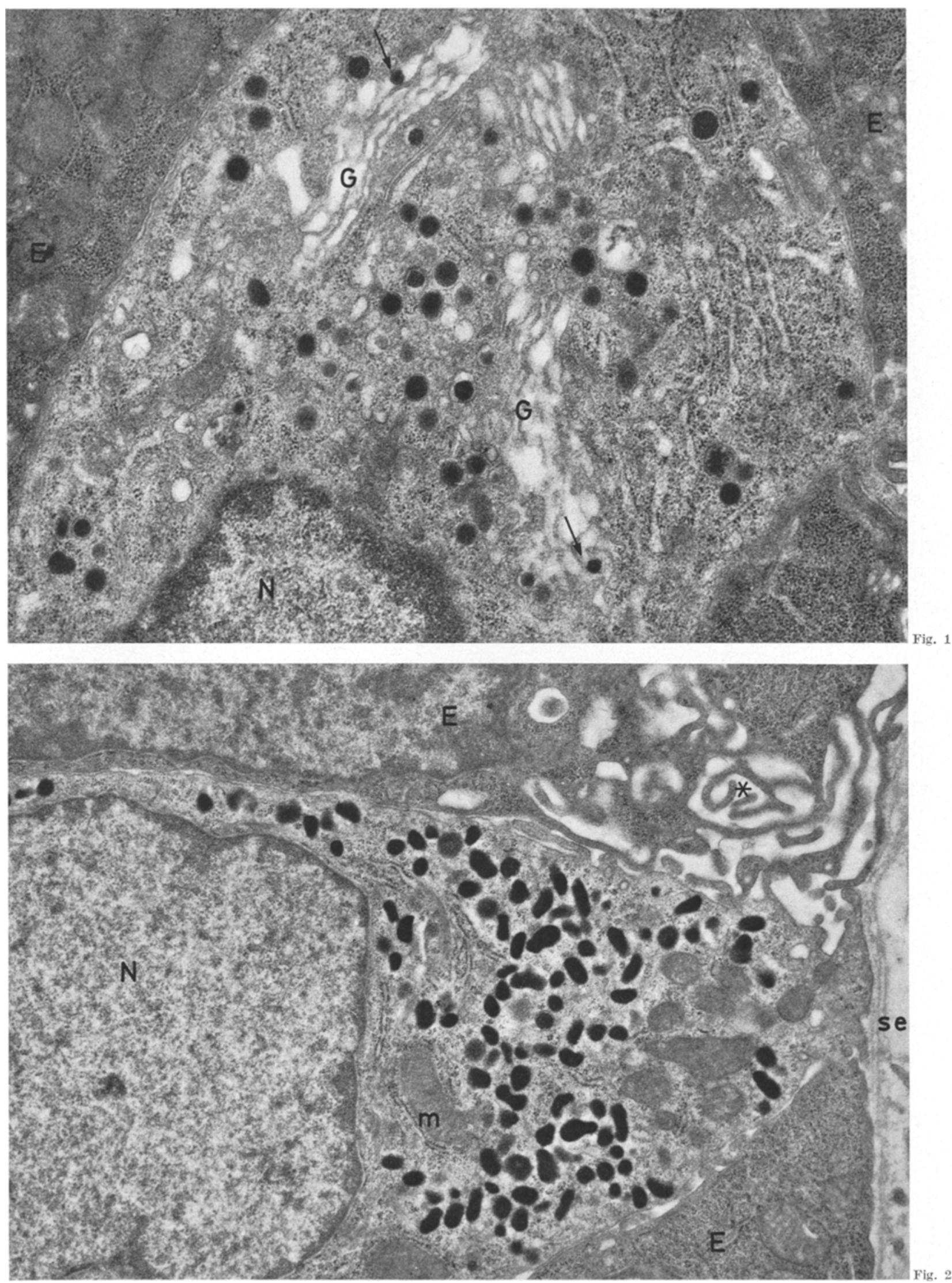

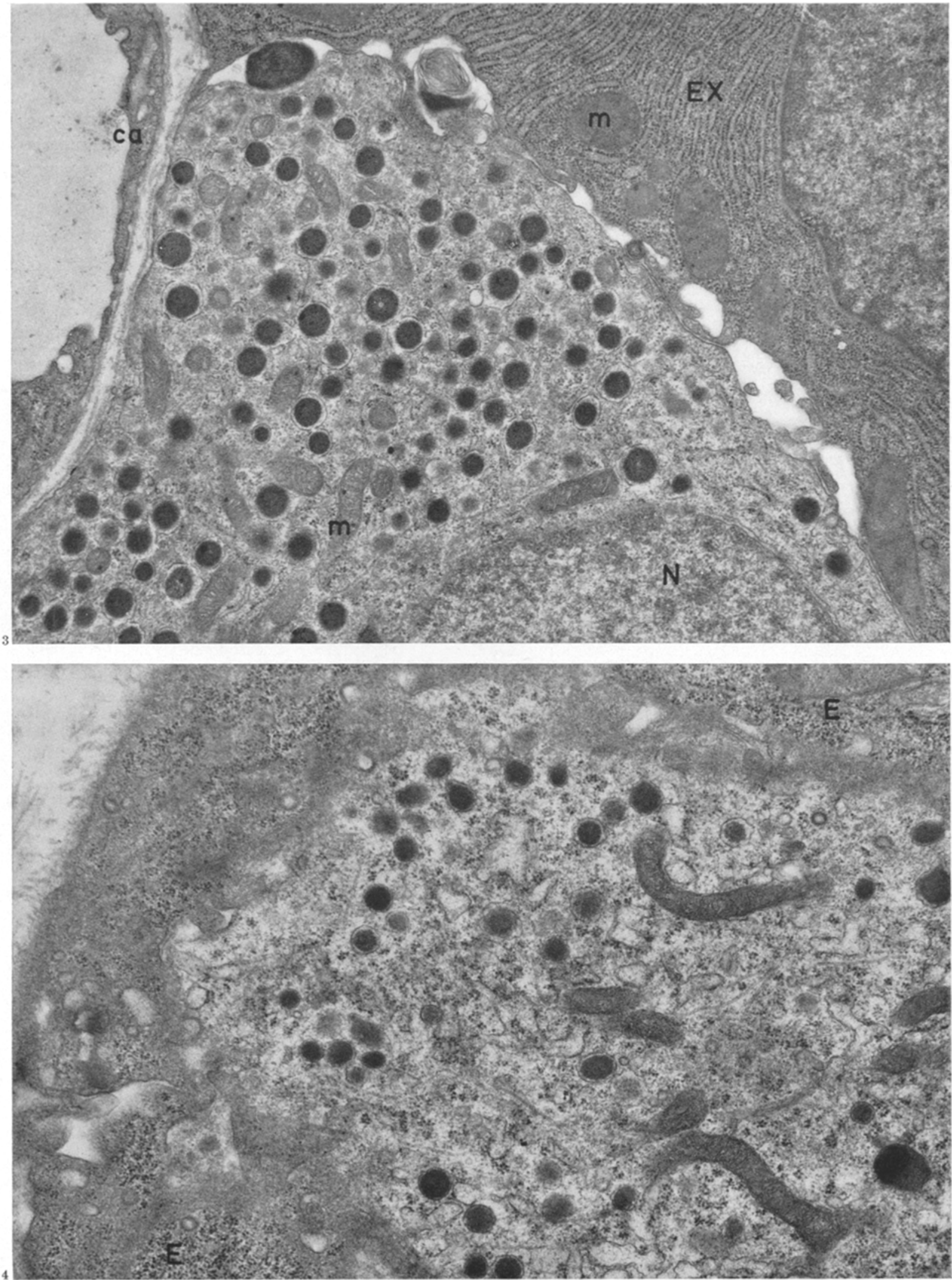

Fig. 3. Panereas: endocrine A-cell. Granules are round and, in most instances, there is an empty space between the granule and its membrane. At the upper righthand corner, there is a trpical exocrine cell (Ex); at the left border a capillary (ca). Nucleus (N); mitochondria (m); enlarged $26000 \times$

Fig.4. Jejunum: cell of type $\mathrm{I}$ (enteroglucagon). The granules, although less numerous, are very similar in appearance to those in Figs. 1 and 8 . A moderate number of filaments is seen in the cytoplasm. Epithelial cells $(\mathbf{E})$; enlarged $20000 \mathrm{x}$ 

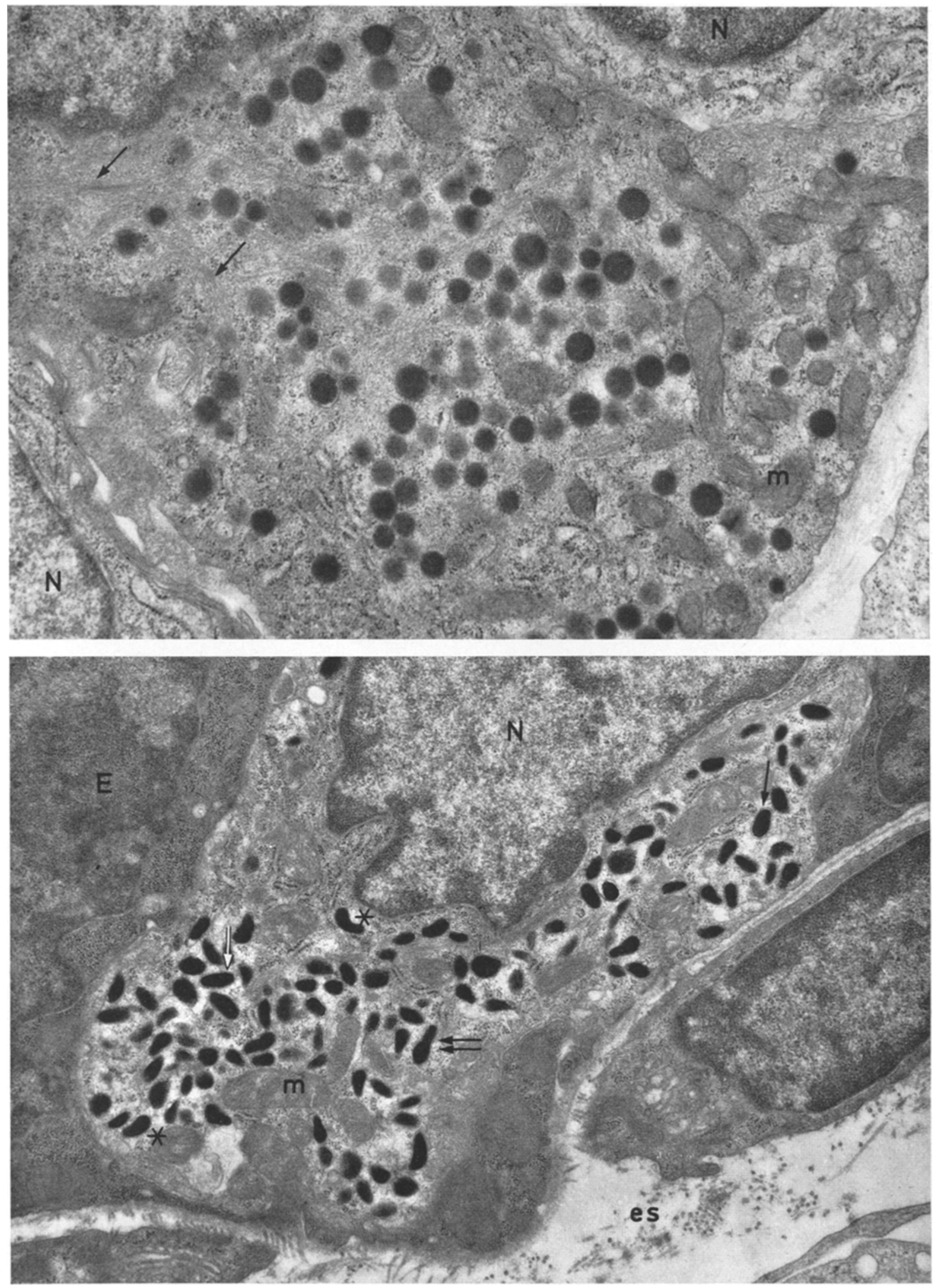

Fig. 5. Heum: type I cell (enteroglucagon). Membrane hug each granule very closely, as also seen in the pancreatic A-cell of Fig. 14. Numerous intracytoplasmic filaments, often grouped in bundles (arrows). Nucleus (N); mitochondria (m); enlarged $21000 \times$

Fig. 6. Duodenum: type II (serotonin). The closely fitting membrane of the granules is clearly visible (arrows) and several kidney-shaped (*) or pear-shaped (double arrow) granules are seen. Nucleus $(\mathrm{N})$; mitochondria $(\mathrm{m})$ subepithelial space (es); epithelial cell $(\mathrm{E})$; enlarged $15000 \times$ 


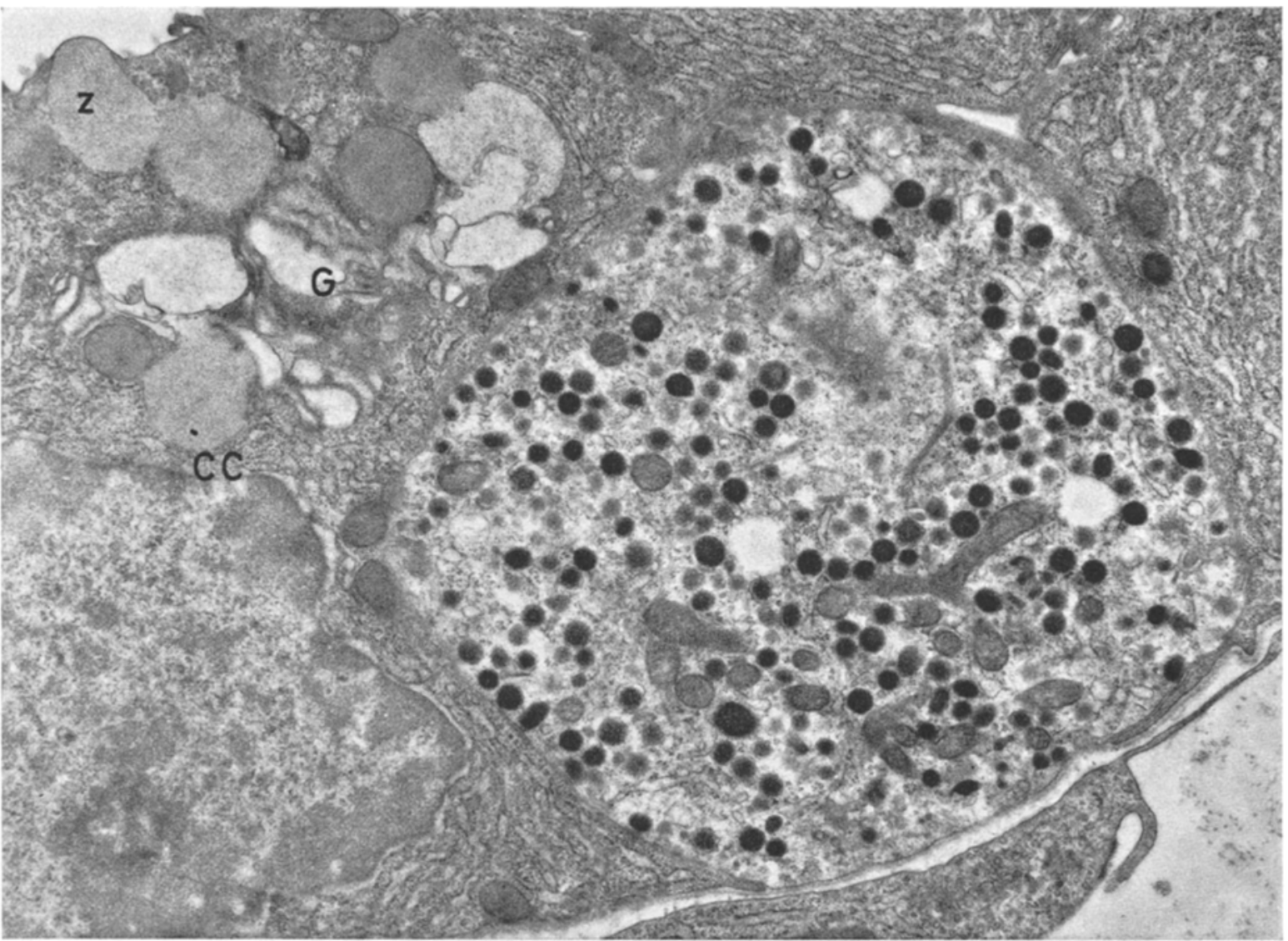

Fig. 7

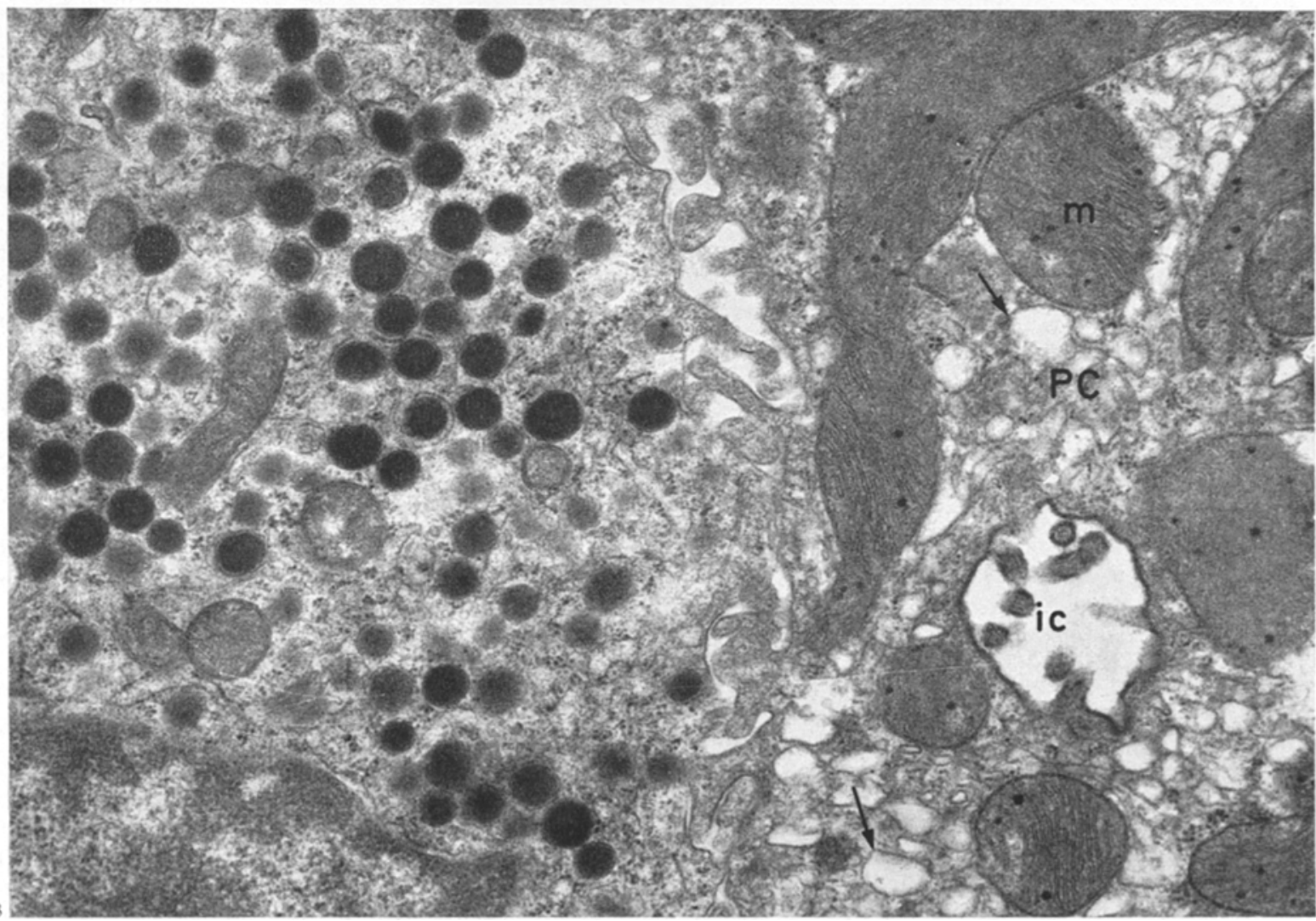

Fig. 7. Fundus: type I cell (enteroglucagon). This type of cell is rounder at this level, rather more like a pancreatic A-cell. There are fewer filaments. At the left, a chief cell (CC). At the upper left hand corner, the glandular lumen is seen, with a zymogen granule ( $z$ ) about to be discharged into it. Golgi complex (G); enlarged $14000 \times$

Fig. 8. Fundus: portion of a type I cell (enteroglucagon). At the right a parietal cell (PC) with smooth vesicles of endoplasmic reticulum (arrows), mitochondria $(\mathrm{m})$ and intracellular duct (ic); enlarged $26000 \times$ 

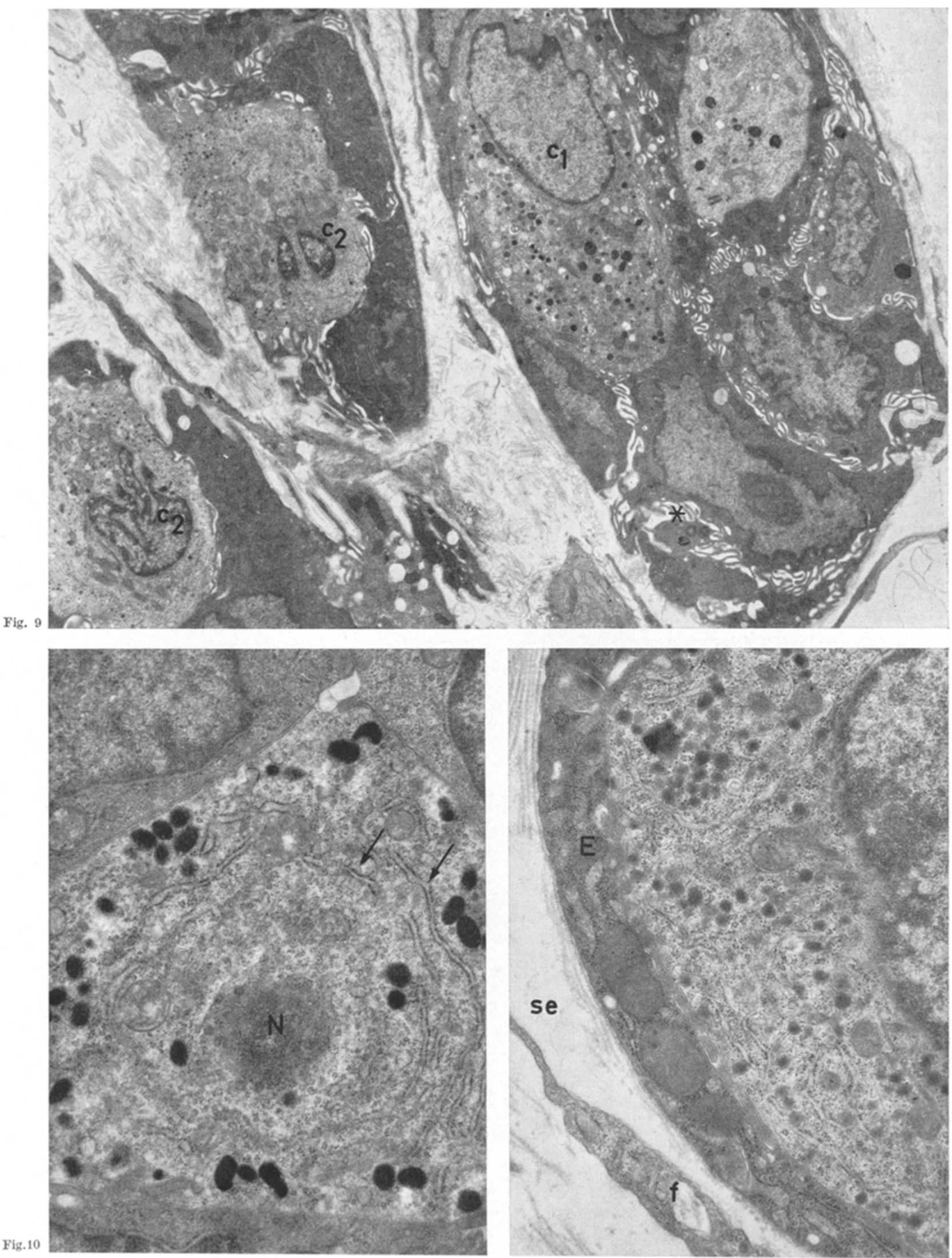

Fig. 9. Pylorus: cross-section through glandular crypts. Two types $\left(e_{1}\right.$ or $\left.e_{2}\right)$ of granule-containing cells are seen. They do not resemble the cells of types I and II seen elsewhere along the digestive tract. Extracellular space (*). Enlarged $4000 \times$

Fig. 10. Duodenum: cross-section of a trpe II cell (serotonin) demonstrating the circular arrangement of the rough endoplasmic reticulum (arrows) close to the nuclear pole (N). Enlarged $16000 \times$

Fig. 11. Pylorus: cell with small granules (comparable with $c_{2}$ in Fig. 9). The granules are much smaller than those of type I or II cells. Epithelial cell (E); sub-epithelial space (se); fibroblast (f); enlarged $16000 \times$ 


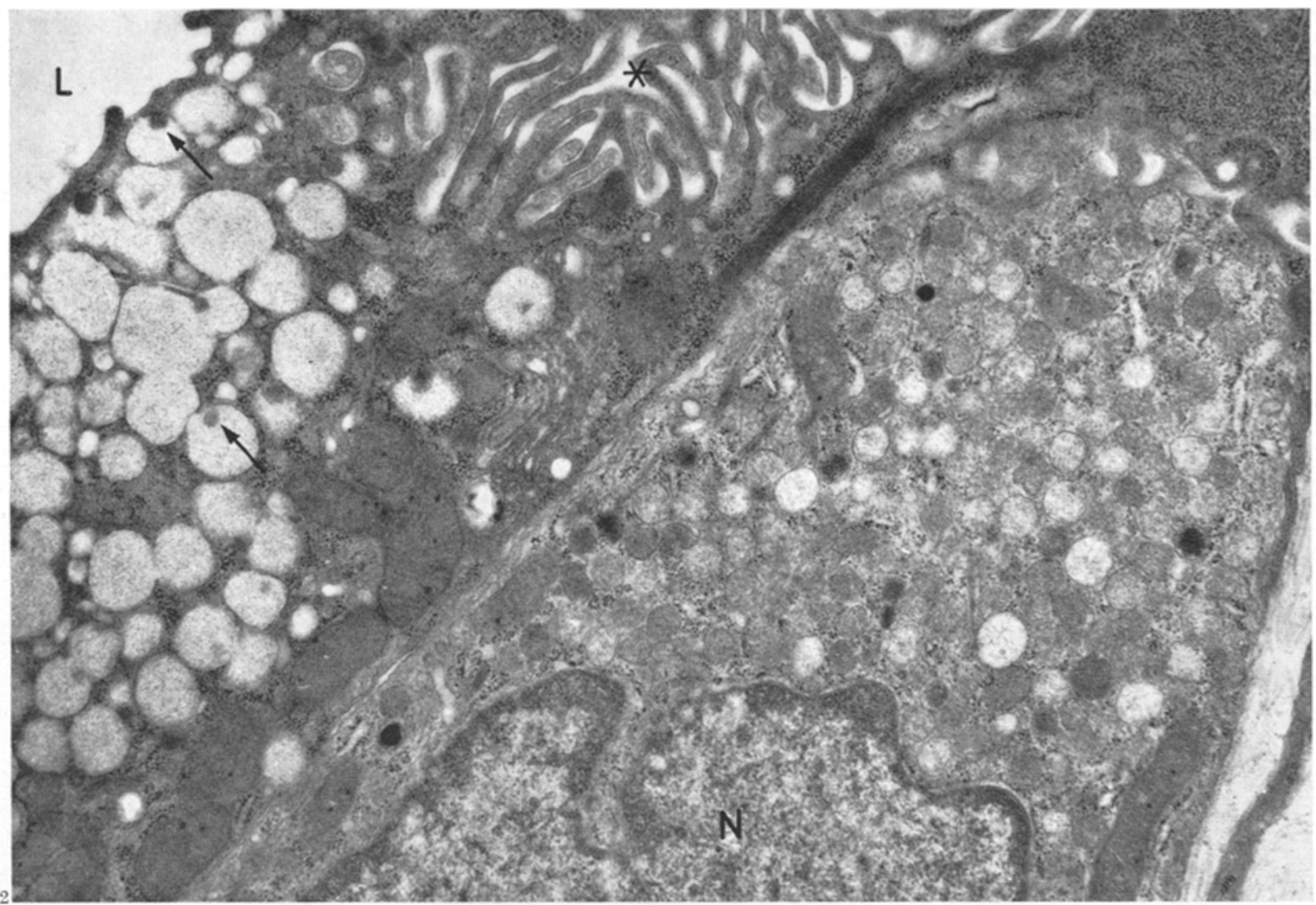

Fig.12

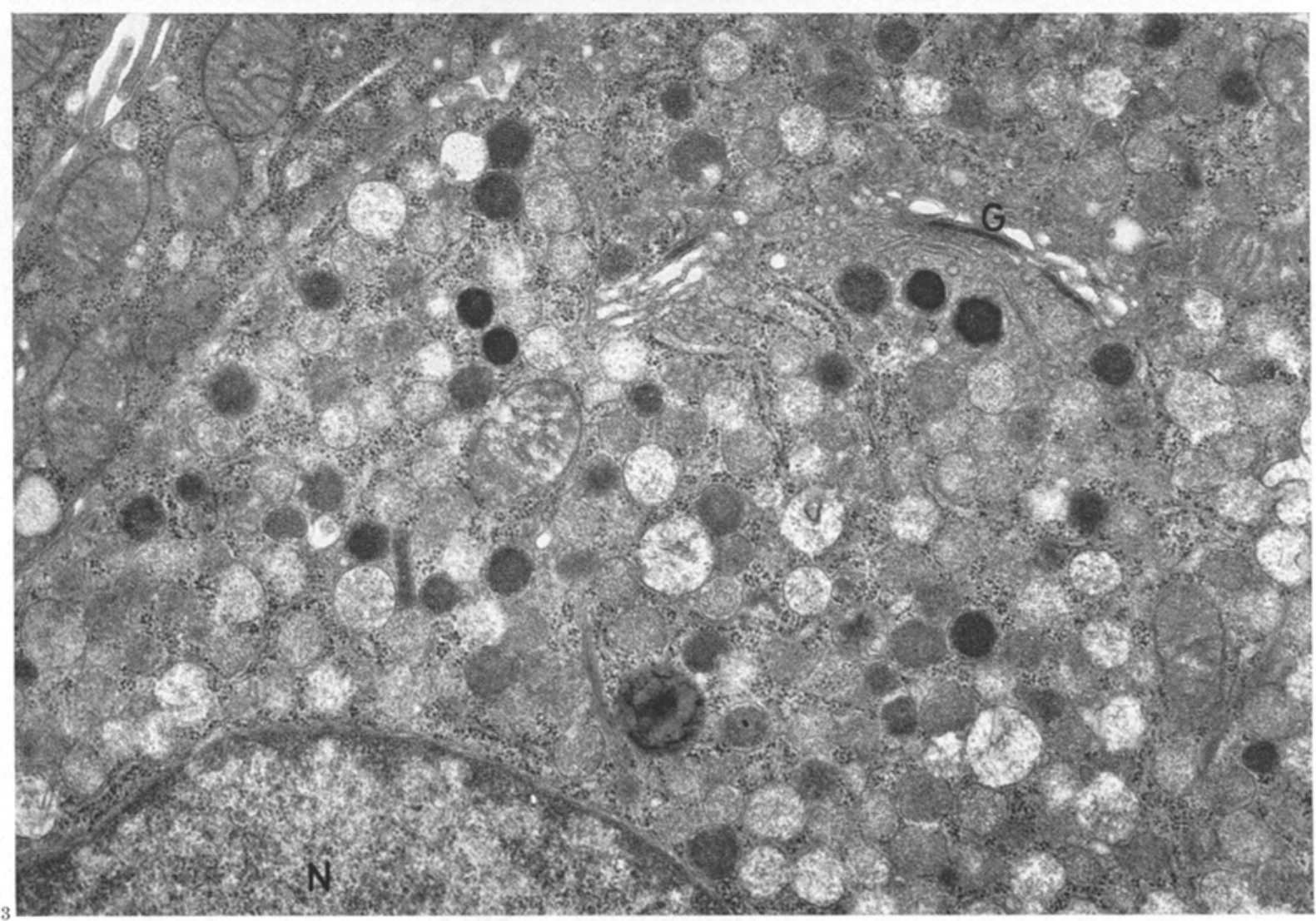

Fig. 12 and 13. Pylorus : example of pyloric cell of type $c_{1}$ (Fig. 9) with numerous vesicles generally containing a material of low electron density. The Golgi complex $(G)$ consists of flattened vacuoles, some of which are next to a very dense band (39). Between this cell and the glandular lumen (L) a mucus-producing cell is seen: the vesicles are larger and contain a still less electron-dense material, with the exception of occasional round inclusions of unknown significance (arrows). Nucleus (N). Extracellular space (*). Fig. 12 enlarged $17000 \times ;$ Fig. 13 enlarged $20000 \times$ 

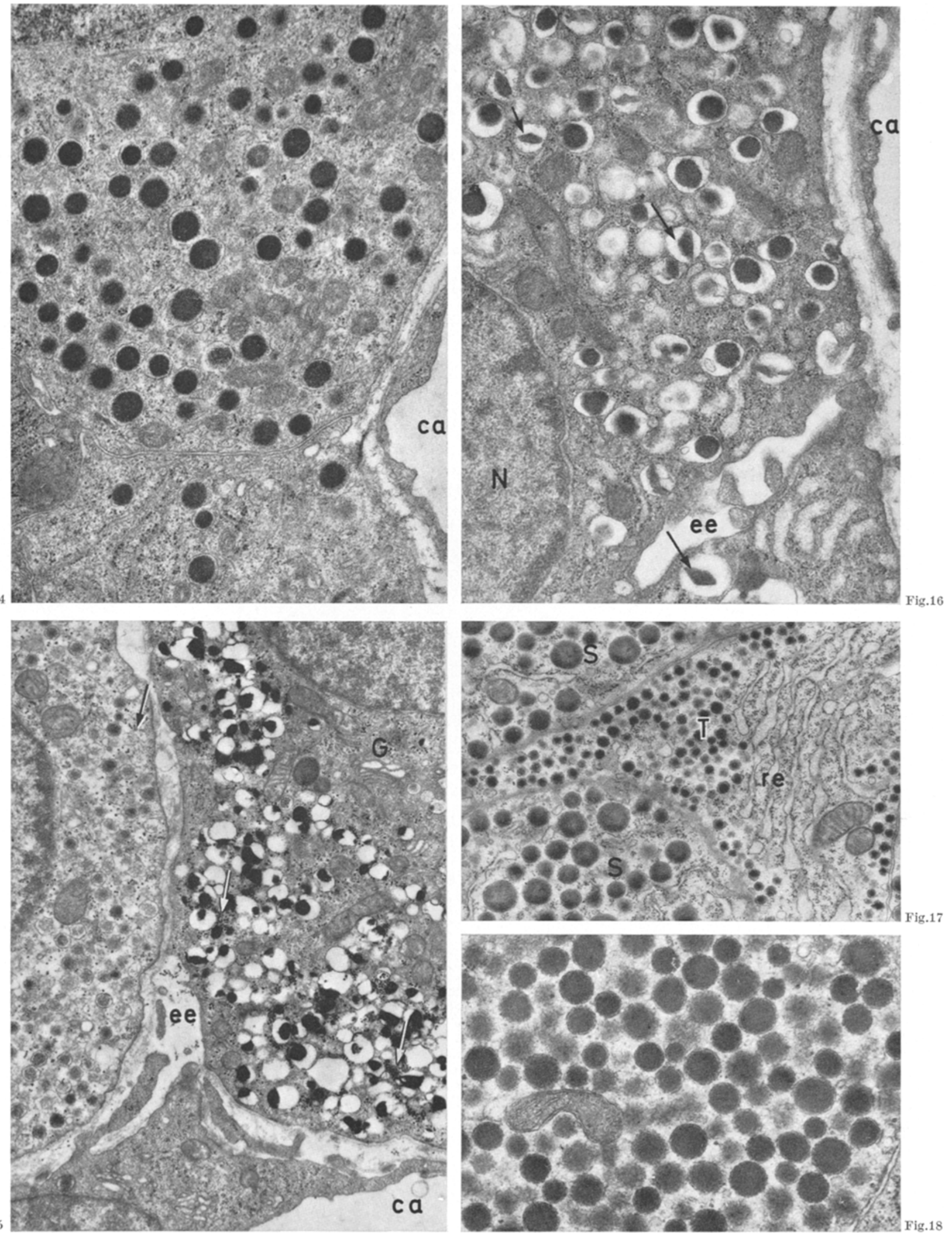

Fig. 14. Pancreatic A-cell: the granular membrane may be more or less apparent, as also seen in the type I intestinal cells (Fig. 5); capillary (ca); enlarged $18000 \times$

Fig. 15. Pancreatic B-cell: the granules are clearly separated from their membrane by a wide empty space. Some of the granules have a crystalloid structure (arrows). Capiliaries (ea); extra-cellular space (ee); nuclens (N); enlarged $21000 \times$

Fig. 16. Adrenal medulla: to the left, an adrenalin-producing cell. A few glycogen granules are seen (arrows). To the right, a noradrenaline-producing cell with more abundant glycogen (arrows). Golgi complex (G); extracellular space (ee); capillary (ca); note the marked difference in the morphology of the granules in the two cells. Enlarged $13000 \times$

Fig. 17. Pituitary of a Spiny mouse (Acomys Cahirinus). TSH-producing cell (T) between two STH-producing cells (\$). Again note the marked difference in the morphology of the granules of the pituitary cells. Rough endoplasmic reticulum (re). Fixation by immersion in $\mathrm{OsO}_{4}$ buffer in veronal-acetate-sucrose. Enlarged $14000 \times$

Fig. 18. Detail of an STH-producing cell demonstrating the relationship of the granules to their membranes. Enlarged $21000 \times$ 
close association with the site of entry of foodstuffs into the organism. We consider it tempting therefore to accept SAMOL's suggestion [32] that glucagon may well be one of the major physiologic mediators of increased insulin secretion by the pancreatic $B$ cells.

In addition, the morphological evidence presented here clearly suggests that the glucagon-like biological and immunologic activity found in the gastrointestinal tract is synthetized locally as in the endocrine pancreas, and not simply stored after synthesis and secretion elsewhere.

\section{References}

1. Caramia, F., B.T. Munger, and P.E. Lacy: The ultrastructural basis for identification of cell types in the pancreatic islets. I. Guinea pig. Z. Zellforsch. 67, $533-566$ (1965).

2. Cavaltero, C., and E. Solcia: Cytological and histochemical aspects of islet pathology in the ZollingerEllison syndrome. Rev. Int. Hepat. XV, 3, 517-526 (1965).

3. - - , and R. SAMPIETRo: Cytology of islet tumours and hyperplasia associated with the Zollinger-Ellison syndrome. Gut 8, 172-177 (1967).

4. DunN, J.S., H. L. Shemhan, and N.G.M. Metetchie: Necrosis of islets of Langerhans produced experimentally. Lancet $1943 \mathrm{I}, 484-487$.

5. ELITN, L.G.: The fine structure of the cell surface of chromaffin cells in the rat adrenal medulla. J. ultrastruct. Res. 12, 263-286 (1965).

6. ERspaler, V., and B. Asero: Identification of enteramine the specific hormone of the enterochromaffin cell system as 5-hydroxytryptamine. Nature 169, $800-801(1959)$.

7a. Forssmann, W., G. Siegrist, L. Orci, L. Girardier, R. Piotet, and Ch. Roullder: Fixation par perfusion pour la microscopie électronique. Essai de généralisation. J. Microscopie 6, 279-304 (1967).

7b. Forssmann, W., L. Orci, R. Pictet, and Ch. RoutlLER: Zur Ultrastructur der endokrinen Zellen im Epithel des Magendarmtracts der Ratte. Comptes rendus de l'Union libre des Anatomistes des Universités suisses Bâle 1967 (sous presse).

8. Friend, D. S.: The fine structure of Brunner's glands in the mouse. J. cell. Biol. 25, 563-576 (1965).

9. Gomori, G.: A now stain for elastic tissue. Amer. J. clin. Path. 20, 665 (1950).

10. GoneT, A.E., and A.E. Renold: Homografting of fetal rat pancreas. Diabetologia 1, $91-96$ (1965).

11. HELANDER, H.F.: Ultrastructure of secretory cells in the pyloric gland area of the mouse gastric mucosa. J. ultrastruct. Res. 10, 145-159 (1964).

12. Hellerstrom, C., B. Heltiman, B. Petersson, and G. ALM: The two types of pancreatic A-cells and their relation to glucagon secretion. In: Symposium on the structure and metabolism of the pancreatic islet, $p$. 117-130. Eds. G.F. Brolin, B. Hellman, and H. Knutson. Oxford: Pergamon Press 1964.

13. Ito, S., and R.J. Winchester: The fine structure of the gastric mucosa in the bat. J. cell. Biol. 16, 541577 (1963).

14. Junod, A., A. E. Lambert, L. Orgt, R. Pictet, A.E. GoNET, and A.E. RENoto: Studies of the diabetogenic action of streptozotocin. Proc. Soc. exp. Biol. in press.

15. KARNOVSKY, M.J.: A simple method for staining with lead at high $\mathrm{pH}$ in electron microscopy. J. biophys. biochem. Cytol. 11, 729-732 (1961).

16. KENNY, A.J., and R.R. SAY: Glucagon-like activity extractable from the gastro-intestinal tract of man and other animals. J. Endocr. 25, $1-7$ (1962).

17. LACY, P.E.: Electron microscopic identification of different cell types in the islets of Langerhans of the guinea pig, rat, rabbit and dog. Anat. Rec. 128, 255$268(1957)$.

18. LEE, D.-H. : Identification of argyrophilic cells in pancreatic islets by light and electron microscopy in osmium-fixed plastic-embedded sections. Z. Zellforsch. 77, $1-7$ (1967).

19. Leeson, C.R., and T.S. Leesor: The fine structure of Brunner's glands in the rat. Anat. Rec. 156, 253$268(1966)$.

20. LIKE, A.A., and E. MikI: Diabetic syndrome in sand rats. IV. Morphologic changes in islet tissue. Diabetologia 3, 143-166 (1967).

21. LUT', J.H.: Improvements in Epoxy resin embedding methods. J. biophys. biochem. Cytol. 9, 409-414 (1961).

22. LusE, S.A., and P.E. LACY: Electron microscopy of a malignant argentaffin tumor. Cancer 13, 334-346 $(1960)$.

23. - F. Caramia, G. Gerritsen, and W. Dulin: Spontaneous diabetes mellitus in the chinese hamster: an electron microscopic study of the islets of Langerhans. Diabetologia 3, 97-108 (1967).

24. MaNocchIo, I.: The metachromatic A-cells in the pancreatic islets of dogs of different age. In: Symposium on the structure and metabolism of the pancreatic islets. Eds. G.F. Brolin, B. Hellman, and H. KNUTson, p. 117-130. Oxford: Pergamon Press 1964.

25. Makman, M.H., and E.W. Sutherland : Use of liver adenyl cyclase for assay of glucagon in human gastro. intestinal tract and pancreas. Endocrinology 75, 127$134(1964)$

26. Melis, M., and L. ORCI: La microscopia a contrasto di fase su ultrasezioni di tessuti e le sue applicazioni in biologia. Ric. Sci. 34, Rend. $B_{4}, 365-410$ (1964).

27. Mertini, D., and F. G. Caramia: Electron microscopic study of the cells of the human pancreatic islets. Rev. int. Hepat. 16, 687-693 (1966).

28. Munger, B.L., F. Caramia, and P.E. Lady: The ultrastructural basis for identification of cell types in the pancreatic islets. II. Rabbit, dog and opossum. Z. Zellforsch. 67, 776-798 (1965).

29a. Orci, L., W.G. Forssmann, R. Pioter, and Ch. Roviller: Mise en évidence des types de cellules à granulations denses dans le système digestif du rat. Société française de microscopie électronique. Colloque de Bruxelles, Mai 1967. J. Microscopie 6, 74 a (1967).

29b. Orct, L., R. Pictet, W. G. Forssmann, A. E. Renold, and Ch. Rotrller: Ultrastructural evidence for ght cagon producing A-cells in the gastrointestinal mucosa of the rat. Proc. of the $6^{\text {th }}$ congr. of the Internat. Diabetes Federation (1967).

30. Pictet, R., L. Orci, A.E. Gonet, Ch. Roulller, and A.E. RENOLD : Ultrastructural studies of the hyperplastic islets of Langerhans of spiny mice (Acomys Cahirinus) before and during the development of hyperglycemia. Diabetologia 3, 188-211(1967).

31. Rennels, E.G.: An electron microscopy study of pituitary autograft cells in the rat. Endocrinology 71, $713-722(1962)$

32. Samols, E., J. Tyler, C. Megyesi, and V. MaRks: Immunochemical glucagon in human pancreas, gut and plasma. Lancet 1966 II, 727-729.

33. SEDAR, A.W., and M.H.F. Friedmax: Correlation of the fine structure of the gastric parietal cell (Dog) with functional activity of the stomach. J. biophys. biochem. Cytol. 11, 349-363 (1961).

34. - The fine structure of the oxyntic cell in relation to functional activity of the stomach. Ann. N.Y. Acad. Sci. 99, 9-29 (1962). 
35. Solcra, E., G. Vassato, and R. Satupietro: Endocrine cells in the antropyloric mucosa of the stomach. $Z$. Zellforsch. (in press).

36. Staley, M.V., and J.S. Trier: Morphologic heterogeneity of mouse Paneth cell granules before and after secretory stimulation. Amer. J. Anat. 117, 365-384 (1965).

37. Sutherland, E.W., and C. DE Duve: Origin and distribution of the hyperglycemic-glycogenic factor of the pancreas. J. biol. Chem. 175, 663-674 (1948).

38. Theret, C., and H. Renault: L'ultrastructure de tumeurs thyréotropes adenohypophysaires expérimentales après radiothyroïdectomie. Bull. Ass. franç. Cancer 51, 505-534 (1964).

39. TURNer, J.R., and W.G. WhalEX: Intercisternal elements of the Golgi apparatus. Science 147, 1303 (1965).

40. UNGer, R.H., H. Ketterer, and A.M. Eisentratt
Distribution of immunoassayable glucagon in gastrointestinal tissues. Metabolism 15, 865-867 (1966).

41. - A. Eisentratu, K. Srms, M.S. MoCall, and L.C. MADISON: Sites of origin of glucagon in dogs and humans. Clin. Res. 9, 53 (1961).

42. Younc, B.A., C.L. Foster, and E. Cameron: Some observations on the ultrastructure of the adenohypophysis of the rabbit. J. Endocr. 31, 279-287 (1965).

43. Zolutnger, R.M., and E. Ellison: Primary peptic ulcerations of the jejunum associated with islet cell tumor of the pancreas. Ann. Surg. 142, 709 (1955).

Dr. LeLito OrCI

Department of Histology and Embryology

University of Geneva

Geneva, Switzerland 